\title{
Prevalence and associated factors of subclinical atherosclerosis in rheumatoid arthritis at the university hospital of Kinshasa
}

Christophe Mulumba ${ }^{1 *}$, Pierrot Lebughe ${ }^{1}$, Jean-Marie Mbuyi-Muamba', Jean-Robert Makulo², François Lepira², Jean Mukaya ${ }^{3}$, Rene Westhovens ${ }^{4}$, Patrick Verschueren ${ }^{4}$ and Jean-Jacques Malemba'

\begin{abstract}
Background: Rheumatoid arthritis (RA) is associated with a 5 to 10 years reduction in life expectancy due to premature atherosclerosis. This reduction is the consequence of traditional cardiovascular risk factors (TCRF) as well as systemic inflammation. The aim of the present study was to describe the prevalence and factors associated with subclinical atherosclerosis in RA at the University Hospital of Kinshasa (UHK).

Methods: Patients with a diagnosis of RA based on the 2010 ACR/EULAR criteria were included in this crosssectional study from 1 June 2014 to 31 May 2015 at the UHK. RA disease activity was measured using the DAS28ESR. Active RA was defined by a DAS $28>2.6$. Severe RA was defined by the presence of extra-articular manifestation, joint erosions on $\mathrm{X}$-rays or $\mathrm{HAQ} \geq 0.5$. An assessment of subclinical atherosclerosis was performed by the measurement of the carotid intima-media thickness (cIMT) using two-dimensional ultrasonography. Subclinical atherosclerosis was defined by a CIMT $\geq 0.9 \mathrm{~mm}$. A diagnosis of atheroma plaque was retained when the cIMT was $\geq 1.5 \mathrm{~mm}$. The association between subclinical atherosclerosis and potential risk factors was modeled using logistic regression analysis.

Results: We recruited 75 patients. The average age was $51.8 \pm 14.6$ years, with a sex ratio F/M of 4 . The prevalence of subclinical atherosclerosis was $32 \%$. In logistic regression being a woman of $\geq 55$ years old (aOR $10.6,95 \% \mathrm{Cl}$ [2.087-53.82], $p=0.028), \mathrm{DAS} 28-\mathrm{ESR}>2.6$ (aOR 3.5,95\% Cl [1.55-10.38], $p=0.044$ ), severe RA (aOR 32.6,95\% Cl $[1.761-60.37], p=0.035)$, high blood pressure (aOR 22.4,95\% Cl [5.04-99.41], $p=0.005)$ and obesity (aOR 32.3, 95\% Cl [2.606-40.73], $p=0.026$ ) emerged as factors associated with subclinical atherosclerosis.

Conclusion: Subclinical atherosclerosis is common in RA patients attending the UHK. It appears to be associated with RA disease activity and severity apart from traditional cardiovascular risk factors. These results suggest that early management of subclinical atherosclerosis targeting remaining RA disease activity and cardiovascular risk factors could slow down progression to clinical cardiovascular disease.
\end{abstract}

Keywords: Rheumatoid arthritis, Subclinical atherosclerosis, cIMT

\footnotetext{
* Correspondence: mulumbachristophe@gmail.com

'Rheumatology Unit, Department of internal medicine, University Hospital of

Kinshasa, Kinshasa, Democratic Republic of Congo

Full list of author information is available at the end of the article
}

(c) The Author(s). 2019 Open Access This article is distributed under the terms of the Creative Commons Attribution 4.0 International License (http://creativecommons.org/licenses/by/4.0/), which permits unrestricted use, distribution, and reproduction in any medium, provided you give appropriate credit to the original author(s) and the source, provide a link to the Creative Commons license, and indicate if changes were made. The Creative Commons Public Domain Dedication waiver (http://creativecommons.org/publicdomain/zero/1.0/) applies to the data made available in this article, unless otherwise stated. 


\section{Background}

Rheumatoid arthritis (RA) is a chronic inflammatory rheumatic condition of autoimmune origin that affects about 0.5 to $1 \%$ of adults worldwide $[1,2]$. Beyond the consequences impairing quality of life, RA is associated with a reduced life expectancy of 5 to 10 years. This is mostly due to a high incidence of cardiovascular disease (CVD) [3-6]. Cardiovascular (CV) morbidity is substantial in RA with a risk of cardiovascular events, as high as that observed in diabetic patients. This risk is 2 to 3 times higher than in the non-diabetic population [7].

This high incidence of CV morbidity and mortality results from earlier and more severe atherosclerosis compared to the general population due in part to a higher prevalence of traditional cardiovascular risk factors (smoking, diabetes, high blood pressure, dyslipidemia, ...) $[8,9]$. But systemic inflammation seems to be the main cause of the high cardiovascular risk in RA. On the one hand, inflammation plays an important role in all stages of atheroma formation, from initiation to thrombosis, and on the other hand, it potentiates the effect of traditional cardiovascular risk factors [10]. The delay since diagnosis, positivity of rheumatoid factor or anticitrullinated peptides antibodies and extra-articular manifestations also increase cardiovascular risk [11, 12].

In Democratic Republic of Congo (DRC), the relationship between atherosclerosis (ATS) and RA has not been evaluated yet. The aim of the present study was to describe the prevalence and associated factors of subclinical atherosclerosis in RA, at the University Hospital of Kinshasa (UHK).

\section{Methods}

Consecutive RA patients were recruited between 1 June 2014 to 31 May 2015 at the rheumatology unit. Patients who suffered from another inflammatory rheumatic disease were not included in the present study. The following parameters were collected: socio-demographic data (age, sex), delay between the disease onset and the first consultation, DAS 28-ESR, joint deformities, extraarticular manifestations (rheumatoid nodes, pericarditis, pleurisies, interstitial pneumonia, etc.), cardiovascular risk factors (smoking, alcoholism, level of physical activity, hypertension, diabetes mellitus, dyslipidemia,use of glucocorticoids), blood pressure $(\mathrm{mmHg})$, body weight $(\mathrm{kg})$, abdominal perimeter $(\mathrm{cm})$, heart rate, height $(\mathrm{cm})$ and BMI $\left(\mathrm{Kg} / \mathrm{m}^{2}\right)$.

The diagnosis of RA was retained according to the 2010 ACR / EULAR criteria. RA disease activity was measured with the DAS28-ESR score (DAS $28=[0.56 \mathrm{x}$ $\sqrt{ } \mathrm{t} 28]+[0.28 \times \sqrt{ } \mathrm{sw} 28]+[0.7 \times \mathrm{Ln}(\mathrm{ESR})]+[0.014 \mathrm{x}$ (VAS-GH)]. The presence of extra-articular manifestations, joint erosions on $\mathrm{X}$-ray and a HAQ $\geq 0.5$ defined a severe RA. Blood pressure was measured 3 times, with measurements taken $2 \mathrm{~min}$ apart, using an OMRON Hem $700 \mathrm{IE}^{\oplus}$ electronic blood pressure monitor. The patient had to be seated since at least 5 minutes and the average of the last two measurements was used for the analyses. The waist circumference (WC) was taken between the last rib and the iliac crest at the end of expiration with a tape measure. The size was taken using a SECA messband $206 \mathrm{~cm}$. The weight was measured, using a KINLee DT01 scale, on a barefoot and slightly dressed patient. Pulse pressure (PP) was calculated as the difference between systolic blood pressure (SBP) and diastolic blood pressure (DBP).

The carotid intima-media (cIMT) thickness was measured by a trained sonographer. This measurement was performed at $2 \mathrm{~cm}$ from the carotid bulb with a LOGIQ C5 Premium color doppler ultrasound. The ultrasound system had a linear high frequency probe of 7.5 to $12 \mathrm{MHz}$. This measurement was performed on the left and right sides of the patient laying down in the supine position, arms along the body and head in moderate extension.

Upon completion of the clinical examination and ultrasonographic measurements of the cIMT, patients were referred to the UHK laboratory for blood sampling between $8 \mathrm{am}$ and $9 \mathrm{am}$ and after a $12 \mathrm{~h}$ fasting period. Fasting plasma glucose was measured using the enzymatic glucose oxidase method. Total cholesterol, triglycerides, HDL-c, uric acid were determined according to enzymatic methods with a semi-automatic device of Humalyser Primus brand. The LDL-c level was calculated using the formula of Friedewald [13]: LDL-c $=$ CT $(\mathrm{mg} / \mathrm{dl})-(\mathrm{HDL}-\mathrm{c})(\mathrm{mg} / \mathrm{dl})$-TG $(\mathrm{mg} / \mathrm{dl}) / 5$. Erythrocytes sedimentation rate (ESR) and $C$ reactive protein were determined according to Westergren and latex agglutination methods respectively. Rheumatoid factor (RF) was measured by an ELISA method.

Hand X-rays were performed in all patients and read by a trained radiologist. Joint space narrowing, erosions and juxta-articular demineralization were looked for.

\section{Definitions of some concepts:}

- Early RA: duration of disease $\leq 2$ years

- Established RA: duration of disease $>2$ years

- synovitis: swollen and/or painful joints

- Obesity (WHO) [14] was defined as a BMI $\geq 30 \mathrm{~kg} / \mathrm{m}^{2}$

- High blood pressure (HBP) was defined as a blood pressure $\geq 140 / 90 \mathrm{mmHg}$ or intake of antihypertensive therapy [15].

- Diabetes mellitus was defined as two fasting glucose levels $\geq 126 \mathrm{mg} / \mathrm{dl}$ or, regardless of blood glucose, intake of anti-diabetic treatment [16].

- Cigarette smoking: Smoking at least 1 cigarette/day for more than 5 years or having stopped smoking for less than 5 years [17]. 
- Alcoholism: defined as a regular intake of 2 or more drinks of beer per day, it being understood that a glass of beer is equivalent to $10 \mathrm{~g}$ of alcohol [18].

- High pulse pressure (PP): $\mathrm{PP}>60 \mathrm{mmHg}$ [19].

- Tachycardia: heart rate (HR) $>90$ beats / min [20].

- Physical inactivity: not being engaged in minimal physical activity defined as the equivalent of a 30 min walk three times weekly [21].

- Metabolic syndrome: was defined according to NCEP-ATP III by the presence of at least 3 of the following criteria: $\mathrm{BP} \geq 130 / 85 \mathrm{mmHg}$ or intake of antihypertensive treatment, waist circumference $>102 \mathrm{~cm}(\mathrm{man})$ and $>88 \mathrm{~cm}$ (women), HDL-c $<40 \mathrm{mg} / \mathrm{dl}$ in man and $<50 \mathrm{mg}$ / dl in women, triglycerides $\geq 150 \mathrm{mg} / \mathrm{dl}$ ), fasting blood glucose $\geq 100 \mathrm{mg} / \mathrm{dl}$ or antidiabetic treatment [22].

- Active RA: DAS $28>2.6$

- Severe RA: presence of extra-articular manifestation, $\mathrm{X}$-rays erosions or HAQ $\geq 0,5$

- High or abnormal ESR: > $16 \mathrm{~mm} / \mathrm{h} 1$ in men, and > $22 \mathrm{~mm} / \mathrm{h} 1 \mathrm{in}$ women.

- Significant inflammatory syndrome: ESR $\geq 60 \mathrm{~mm} / \mathrm{h} 1$ [23].

- Highly positive rheumatoid factor: RF: $>60 \mathrm{IU} / \mathrm{ml}$ [24].

- High or abnormal CRP: CRP $>6 \mathrm{mg} / \mathrm{l}$

- Hyperuricemia: a level of uric acid $>70 \mathrm{mg} / \mathrm{l}$ in men and $>60 \mathrm{mg} / \mathrm{l}$ in women [25].

- Dyslipidemia was characterized by elevated total cholesterol $\geq 200 \mathrm{mg} / \mathrm{dl}$, LDL-c $\geq 130 \mathrm{mg} / \mathrm{dl}$, triglycerides $\geq 150 \mathrm{mg} / \mathrm{dl}$, and HDL-c $<40 \mathrm{mg} / \mathrm{dl}$ in men and $<50 \mathrm{mg} / \mathrm{dl}$ in women [26].

- Subclinical atherosclerosis:cIMT $\geq 0.9 \mathrm{~mm}$. The patient was classified as having an atheroma plaque in case of a cIMT $\geq 1.5 \mathrm{~mm}$ or in the presence of an established atheroma plaque [27].

\section{Statistical analysis}

Data are presented as frequencies, average \pm SD or medians with their extremes. Averages and median were compared using the Student $t$ test and the nonparametric Wilcoxon/Mann Whitney tests respectively. The Pearson Chi-square or Fisher exact tests were applied to compare proportions. A multivariate regression analysis determined factors that were associated to subclinical atherosclerosis. Only variables significantly associated with subclinical atherosclerosis in univariate analysis were tested in multivariable analysis. The collinearity test was used to identify collinear variables if two variables were collinear, only one had entered in the final model of logistic regression in multivariable analysis. Statistical analyses were performed with the SPSS software version 21.0.

\section{Results}

75 RA patients were enrolled during the study period, including 15 males (20\%) and 60 females (80\%). Their average age was $51.8 \pm 14.6$ years. Most patients presented an active, severe and long-lasting disease. The median duration of the disease was 3 years, ranging between 2.4 months and 12 years. Symptoms of synovitis and joint deformities were observed in less than half of patients. The most common extra-articular manifestation was the presence of rheumatoid nodules (Table 1). Rheumatoid factor was negative in most patients. The biologic profile showed a dyslipidemia (elevated total cholesterol and LDLc), high median erythrocyte sedimentation rate and $C$ reactive protein (Table 1). Radiographic lesions were present in $58.7 \%$ patients, and were dominated by juxta-articular demineralization. Erosions and joints space narrowing were less common (Table 1).

\section{Subclinical atherosclerosis}

The average values of the cIMT were similar on the left and the right (Table 2). The prevalence of subclinical atherosclerosis in RA patients was 32\%. Patients with subclinical atherosclerosis were older than those without atherosclerosis. They more often presented an active (DAS28 > 2.6) and severe (having extra-articular manifestations, erosion or $\mathrm{HAQ} \geq 0,5$ ) disease, as well as a higher systolic blood pressure, pulse pressure, waist circumference and BMI than those without subclinical atherosclerosis (Table 3).

The prevalence of traditional cardiovascular risk factors was higher in patients with subclinical atherosclerosis than other patients (Table 3 ). These factors were: being a female $\geq 55$ years old, hypertension, diabetes mellitus, physical inactivity, obesity, metabolic syndrome, hypertriglyceridemia, hypercholesterolemia and hyperuricemia.

In univariate analysis age $\geq 55$ years in females, active RA (DAS28-ESR > 2,6), severe RA, hypertension, diabetes mellitus, physical inactivity, obesity, hypertriglyceridemia and metabolic syndrome were the main factors associated with subclinical atherosclerosis (Table 4). In multivariable analysis this association persisted only for age $\geq 55$ years in female, active disease, severe disease, hypertension and obesity. Risk increased 11 -fold in women $\geq 55$ years old, 33 -fold in patients with severe disease, 22-fold in hypertensive, and 32-fold in obese patients (Table 4)..

\section{Discussion}

The present study described the prevalence of subclinical atherosclerosis in Congolese RA patients and identified its determinants.

The average age of participants was $51.8 \pm 14.6$ years. This is similar to the mean age reported in previous studies conducted in Kinshasa [2, 28, 29]. It should be 
Table 1 Clinical, Biological and hand radiographs characteristics of RA patients in this study

\begin{tabular}{|c|c|c|}
\hline Variables & $n=75$ & $\%$ \\
\hline Age (years), Mean $\pm S D$ & $51.8 \pm 14.6$ & \\
\hline \multicolumn{3}{|l|}{ Sex } \\
\hline Men & 15 & 20.0 \\
\hline Female & 60 & 80.0 \\
\hline \multicolumn{3}{|l|}{ Disease activity (DAS 28-ESR) } \\
\hline Mean \pm SD & $4.9 \pm 1.5$ & \\
\hline Remission & 8 & 10.6 \\
\hline Low disease activity & 5 & 6.7 \\
\hline Moderate disease activity & 23 & 30.7 \\
\hline High disease activity & 39 & 52.0 \\
\hline Severe RA & 47 & 62.7 \\
\hline Duration of RA (years), median (extremes) & $3(0.2-12)$ & \\
\hline Early RA & 18 & 24.0 \\
\hline Established RA & 57 & 76.0 \\
\hline \multicolumn{3}{|l|}{ Joint manifestations } \\
\hline Synovitis & 51 & 68 \\
\hline Joint deformities & 26 & 34.7 \\
\hline None & 15 & 20.0 \\
\hline \multicolumn{3}{|l|}{ Extra-articular manifestations } \\
\hline Rheumatoid nodule & 12 & 16 \\
\hline Interstitial pneumonia & 2 & 2.7 \\
\hline Sicca syndrome & 3 & 4.0 \\
\hline None & 59 & 78.7 \\
\hline
\end{tabular}

Rheumatoid factor, n (\%)

RF-

RF-

Glycemia, mg/dl

Uric acid, $\mathrm{mg} / \mathrm{dl}$

Total cholesterol, mg/dl

$84.2 \pm 21.7$

$4.5 \pm 1.6$

$229.1 \pm 48.7$

LDLc, mg/dl

HDLc, mg/dl

Triglycerides, mg/dl

ESR, mm/h1

CRP, $\mathrm{mg} / \mathrm{l}$

$161.1 \pm 42.2$

$40.3 \pm 13.5$

$147.3 \pm 44.5$

$40(8-145)$

$12(6-72)$

Characteristics of hand radiographs

$\begin{array}{lll}\text { Normal } & 31 & 41.3 \\ \text { Juxta-articular demineralization } & 35 & 46.7 \\ \text { Erosion } & 4 & 5.3 \\ \text { Juxta-articular demineralization + erosion } & 3 & 4.0\end{array}$

Juxta-articular demineralization + erosion + joint

space narrowing

2

DAS 28: Disease activity score; SD Standard deviation; RF Rheumatoid Factor; LDLC Low density Lipoprotein; HDLC High density lipoprotein; ESR Erythrocyte sedimentation rate; $C R P C$ reactive protein

Table 2 Mean values of CIMT in RA patients with or without subclinical atherosclerosis

\begin{tabular}{llll}
\hline Variables & $\begin{array}{l}\text { all } \\
n=75\end{array}$ & $\begin{array}{l}\text { ATS }- \\
n=51\end{array}$ & $\begin{array}{l}\text { ATS }+ \\
n=24\end{array}$ \\
\hline $\begin{array}{llll}\text { CIMT, (mm) } \\
\text { CIMT right }\end{array}$ & $0.74 \pm 0.17$ & $0.64 \pm 0.11$ & $0.95 \pm 0.07$ \\
CIMTleft & $0.73 \pm 0.18$ & $0.62 \pm 0.11$ & $0.95 \pm 0.06$ \\
\hline cIMT Carotid intima-media thickness & &
\end{tabular}

reminded that RA occurs most often between 35 and 50 years of age. The female predominance observed in the present study confirms what is described in the literature [30]. More than half of patients had an established and active RA with a median disease duration of 3 years. This observation suggests that patients consulted rather late. This delay could be the result of ignorance or underreporting of patients, poverty, the use of traditional medicine and especially self-medication.

The proportion of patients with rheumatoid factor was lower than those reported in Senegal [31], Togo [32] and especially in the Western countries [33]. A similar observation has already been made in previous studies conducted in DR Congo [28]. The fact that more than half of the patients were rheumatoid factor negative potentially contributes to the less destructive nature of the disease, as evidenced by the rarity of articular erosions on radiography [34].

Three out of 10 patients had subclinical atherosclerosis. This frequency is similar to those reported by Kassem et al. in 2010 (33.3\%) [25], Hannawi et al. (2007) [35\%], Grovers et al. [33.3\%] [35] and Gonzalez et al. in 2003 (34\%) [26]. On the other hand, it was higher than that reported by Mahajan et al. in 2008 (21\%) [36] and lower than that reported by Mohan et al. in 2014 (59.3\%) [37]. Differences in the frequency of subclinical atherosclerosis between studies may, in part, be explained by the difference in the thresholds used to define subclinical atherosclerosis.

Patients with subclinical atherosclerosis had a significantly higher SBP and PP values than those without atherosclerosis. Indeed, the association between SBP, PP and subclinical atherosclerosis generally reflects the loss of the elasticity of the arterial wall of the aorta which becomes rigid, explaining the elevation of SBP as well as the decrease of DBP; and consequently the elevation of the PP [38].

The present study did not show a significant association between subclinical atherosclerosis and the duration of the disease. These results corroborate those of Jonsson et al. [39], as well as Alkaabi et al. [40]. In contrast, Kumeda et al. and Park et al. reported an association between disease duration and subclinical atherosclerosis. So, chronic inflammation is the basis of long-term progression of RA which is closely linked to the development of subclinical atherosclerosis [41, 42]. 
Table 3 Clinical, biological characteristics and traditional cardiovascular risk factors of patients with or without subclinical atherosclerosis

\begin{tabular}{|c|c|c|c|}
\hline Variables & ATS $+(n=24)$ & ATS- $(n=51)$ & $\mathrm{p}$ \\
\hline Age (years) & $60.4 \pm 11.0$ & $47.8 \pm 14.4$ & $<0.0001$ \\
\hline Female age $\geq 55$ years, $n(\%)$ & $15(75.0)$ & $16(40.0)$ & 0.010 \\
\hline Male age $\geq 45$ years,n (\%) & $4(100.0)$ & $10(55.6)$ & 0.137 \\
\hline Established RA, n (\%) & $15(62.5)$ & $42(82.4)$ & 0.005 \\
\hline Median duration of RA (years) & $2(0.3-12.0)$ & $2(0.2-12.0)$ & 0.850 \\
\hline DAS28-ESR > 2,6 n (\%) & $23(95.8)$ & $39(76.5)$ & $>0.034$ \\
\hline Severe RA, n (\%) & $18(66.7)$ & $29(56.9)$ & 0.029 \\
\hline Dose of MTX, mg/week & $7.8 \pm 1.5$ & $8.5 \pm 2.2$ & 0.153 \\
\hline Duration of corticosteroid use, month, median (extremes) & $1(1.0-6.0)$ & $2(0.5-12.0)$ & 0.975 \\
\hline Heart rate, bpm & $81.1 \pm 15.2$ & $81.3 \pm 10.2$ & 0.949 \\
\hline $\mathrm{SBP}, \mathrm{mmHg}$ & $137.9 \pm 19.4$ & $125.3 \pm 19.5$ & 0.010 \\
\hline $\mathrm{DBP}, \mathrm{mmHg}$ & $79.1 \pm 9.4$ & $77.2 \pm 10.8$ & 0.447 \\
\hline $\mathrm{PP}, \mathrm{mmHg}$ & $58.3 \pm 18.7$ & $49.9 \pm 14.2$ & 0.034 \\
\hline Waist cicumference, cm & $94.9 \pm 11.3$ & $86.7 \pm 11.8$ & 0.006 \\
\hline $\mathrm{BMl}, \mathrm{Kg} / \mathrm{m} 2$ & $26.7 \pm 4.9$ & $22.7 \pm 4.2$ & 0.001 \\
\hline $\mathrm{HBP}, \mathrm{n}(\%)$ & $14(58.3)$ & $7(13.7)$ & $<0.0001$ \\
\hline Diabetes mellitus, n (\%) & $7(29.2)$ & $3(5.9)$ & 0.010 \\
\hline Physical inactivity, n (\%) & $19(79.2)$ & $22(43.1)$ & 0.003 \\
\hline Alcoholism, n (\%) & $8(33.3)$ & $13(25.5)$ & 0.330 \\
\hline Tobacco use, n (\%) & $1(4.2)$ & $1(2.0)$ & 0.541 \\
\hline Global Obesity, n (\%) & $8(33.3)$ & $1(2.0)$ & $<0.0001$ \\
\hline Overweight, n (\%) & $9(37.5)$ & $13(25.5)$ & 0.212 \\
\hline $\mathrm{PP}>60 \mathrm{mmHg}, \mathrm{n}(\%)$ & $7(29.2)$ & $15(29.4)$ & 0.603 \\
\hline Metabolic syndrome, n (\%) & $9(37.5)$ & $10(19.6)$ & 0.008 \\
\hline Low HDL-C, n (\%) & $7(29.2)$ & $13(25.5)$ & 0.471 \\
\hline Hypertriglyceridemia, n (\%) & $16(66.7)$ & $20(39.2)$ & 0.024 \\
\hline Hypercholesterolemia, n (\%) & $19(79.2)$ & $31(60.8)$ & 0.009 \\
\hline High LDL-c,n (\%) & $18(75.0)$ & 35 (68.6) & 0.390 \\
\hline Glycaemia,mg/dl & $85.1 \pm 22.4$ & $83.7 \pm 21.6$ & 0.798 \\
\hline $\mathrm{RF}+, \mathrm{n}(\%)$ & $8(33.3)$ & $24(47.1)$ & 0.192 \\
\hline ESR,mm/h1,median (extremes) & $40.5(8-115)$ & $40.0(13-145)$ & 0.866 \\
\hline CRP, median (extremes) & $24.0(6-72)$ & $21(6-72)$ & 0.775 \\
\hline
\end{tabular}

RA Rheumatoid arthritis; MTX Methotrexate; HR Heart rate; bpm Beats per minute; PP Pulse pressure;SBP Systolic blood pressure; DBP Diastolic blood pressure; BMI Body mass index; RF Rheumatoid factor; ESR Erythrocyte sedimentation rate; CRP C reactive protein. $H B P$ High blood pressure; $H D L C$ High density lipoprotein; $L D L C$ Low density lipoprotein; SD Standard deviation

Being a woman $\geq 55$ years old, disease activity level and severity of the disease, hypertension as well as obesity emerged as the main factors independently associated with subclinical atherosclerosis. The impact of age in the development and progression of atherosclerosis has been demonstrated in several studies [43, 44]. Age is a potent cardiovascular risk factor. It participates in the appearance of vascular lesions induced by the oxidative stress and inflammation. These lesions lead to the development of other risk factors such as hypertension, and atherosclerosis. In addition to that, age in women $\geq 55$ years corresponds to the menopausal period which contributes to the occurrence of subclinical atherosclerosis. Indeed, the decrease in oestradiol during menopause results in an atherogenic lipid profile and endothelial dysfunction responsible for an increased cardiovascular risk [44]. Our results are similar to those of Dionicio et al. reported in 2012 [45]. In contrast, Rawhya et al. reported only an association with disease activity [46]. 
Table 4 Multivariate regression analysis of factors associated with subclinical atherosclerosis

\begin{tabular}{|c|c|c|c|c|}
\hline \multirow[t]{2}{*}{ Variables } & \multicolumn{2}{|l|}{ Univariateanalysis } & \multicolumn{2}{|l|}{ Multivariateanalysis } \\
\hline & OR $(95 \% \mathrm{Cl})$ & $p$ & aOR (95\%Cl) & $p$ \\
\hline \multicolumn{5}{|l|}{ Age (women) } \\
\hline$<55$ years & 1 & & 1 & \\
\hline$\geq 55$ years & $4.5(1.36-14.84)$ & 0.014 & $10.6(2.09-53.82)$ & 0.028 \\
\hline \multicolumn{5}{|l|}{ Active RA } \\
\hline Inactive & 1 & & 1 & \\
\hline DAS 28-ESR>2.6 & $7.5(1.85-9.16)$ & 0.007 & $3.5(1.16-10.38)$ & 0.044 \\
\hline \multicolumn{5}{|l|}{ Severe RA } \\
\hline Not severe & 1 & & 1 & \\
\hline severe & $3.6(1.13-4.74)$ & 0.007 & $32.6(1.76-60.37)$ & 0.035 \\
\hline \multicolumn{5}{|c|}{ High sedimentation rate } \\
\hline No & 1 & & 1 & \\
\hline yes & $5.0(1.53-7.29)$ & 0.016 & $1.0(0.99-1.08)$ & 0.123 \\
\hline \multicolumn{5}{|l|}{ HBP } \\
\hline No & 1 & & 1 & \\
\hline yes & $15.0(2.18-20.04)$ & 0.006 & $22.4(5.04-29.41)$ & 0.005 \\
\hline \multicolumn{5}{|l|}{ Diabetes mellitus } \\
\hline No & 1 & & 1 & \\
\hline yes & $7.0(1.11-14.06)$ & 0.038 & $1.5(0.31-3.09)$ & 0.216 \\
\hline \multicolumn{5}{|l|}{ Physical inactivity } \\
\hline No & 1 & & 1 & \\
\hline yes & $8.3(1.88-12.01)$ & 0.006 & $1.4(0.48-4.81)$ & 0.189 \\
\hline \multicolumn{5}{|l|}{ Global obesity } \\
\hline No & 1 & & 1 & \\
\hline yes & $25.0(2.9-45.42)$ & 0.003 & $32.3(2.61-40.73)$ & 0.026 \\
\hline
\end{tabular}

$R A$ Rheumatoid arthritis; SR Sedimentation rate; $H B P$ High blood pressure; $a O R$ Adjusted odds ratio

The present study did not observe an association between CRP and subclinical atherosclerosis. This result must be considered with caution because of the small size of our sample. Apart from that, we have used a quantitative method of CRP with a cutoff of $6 \mathrm{mg} / \mathrm{l}$ (the most commonly available in our country). With this method CRP values and cutoffs are higher compared to the ultrasensitive method and may have underestimated the number of patients with high CRP level. So, it is possible that by using an ultrasensitive method, we might have found an association between CRP and subclinical atherosclerosis.

The activity and severity of the disease have also been implicated in the occurrence of subclinical atherosclerosis. Systemic inflammation, which can precede the onset of joint symptoms in RA, may favor the development of atheromatous disease before joint manifestations. The pathogenesis of atherosclerosis is related to that of autoimmune joint disease $[47,48,49]$. Systemic inflammation may also be associated with obesity (pro-inflammatory state) and induce insulin resistance, changes in lipid profile and, consequently, development of metabolic syndrome in patients with active RA $[50,51]$. So, the control of inflammation and management of traditional risk factors should normally reduce the occurrence of early atherosclerosis.

The present study has some limitations. First, the small sample size cannot provide enough power for the statistical tests used to detect possible associations. Second, the cross-sectional nature of this study excludes any possibility to establish a causal relationship. Third, the lack of measurement of ACPA in our study is also a limitation since ACPA may be related to the increasing of cardiovascular risk. These limitations may be solved by a case-control study or a longitudinal study on a large sample.

However, this study has the merit of being the first to describe the prevalence of subclinical atherosclerosis in Congolese RA patients and to identify its associated factors. Moreover, it shows that the measurement of the cIMT may be used as a simple and reliable tool for detecting subclinical atherosclerosis, and identifying patients who are most likely to benefit from preventive measures.

\section{Conclusion}

The current study showed that subclinical atherosclerosis is frequent (32\%) among patients suffering from rheumatoid arthritis at the University Hospital of Kinshasa. It is associated with traditional cardiovascular risk factors and RA disease characteristics. Patients with subclinical atherosclerosis had a more active and severe disease than those without subclinical atherosclerosis. These results suggest that screening and early management of subclinical atherosclerosis and risk factors in patients with RA could slow down the progression to clinical cardiovascular disease.

\section{Abbreviations}

ACR: American College of Rheumatology; aOR: Adjusted odds ratio; CIMT: Carotid intima-media thickness; CRP: C reactive protein; CV: Cardiovascular; CVD: Cardiovascular disease; DAS-28: Disease activity score; DBP: Diastolic blood pressure; ESR: Erythrocyte sedimentation rate; EULAR: European League against Rheumatism; HAQ: Health assessment questionnaire; HDLc: High density lipoprotein; LDLc: Low density lipoprotein; PP: Pulse pressure; RA: Rheumatoid arthritis; RF: Rheumatoid factor; SBP: Systolic blood pressure; SD: Standard deviation; TCRF: Traditional cardiovascular risk factors; UHK: university hospital of Kinshasa

\section{Acknowledgements}

We would like to thank Doctor LUKUSA and laboratory technicians of the University Hospital of Kinshasa for their contributions to the paper.

\section{Authors' contributions}

CM participated in the design, data collection and writing of the manuscript. $J J M, P L, J M M$ were involved in the design and writing of the manuscript. FL, JRM, JM, RW and PV participated in the writing of the manuscript. All authors have read and approved the manuscript. 


\section{Funding}

This work received no financial assistance from any funding agency in the public, commercial or non-profit sectors.

\section{Availability of data and materials}

All Data used and analysed during the current study are available from the corresponding author on reasonable request.

\section{Ethics approval and consent to participate}

The study protocol was approved by the Clinical Research Ethics Committee of Public Health's School (Kinshasa, DRC), number ESP/CE/106/2015. Patient recruitment was based on free and informed verbal consent, in accordance with the Helsinki recommendations. They were informed on the objectives of the study, its outcome, its safety and its merits.

\section{Consent for publication}

Not applicable.

\section{Competing interests}

The authors declare that they have no competing interests.

\section{Author details}

${ }^{1}$ Rheumatology Unit, Department of internal medicine, University Hospital of Kinshasa, Kinshasa, Democratic Republic of Congo. ${ }^{2}$ Nephrology Unit, Departement of internal medicine, University Hospital of Kinshasa, Kinshasa, Democratic Republic of Congo. ${ }^{3}$ Radiology Unit, Department of internal medicine, University Hospital of Kinshasa, Kinshasa, Democratic Republic of Congo. ${ }^{4}$ Department of Rheumatology, University Hospitals Leuven, Leuven, Belgium.

\section{Received: 7 December 2017 Accepted: 25 August 2019}

Published online: 09 September 2019

\section{References}

1. Saraux A, Guedes C, Allain J, Devauchelle V, Valls I, Lamour A, et al. Prevalence of rheumatoid arthritis and spondyloarthropathy in Brittany, France. Société de Rhumatologie de l'Ouest, J Rheumatol. 1999;26:2622-7.

2. Malemba JJ, Mbuyi-Muamba JM, Mukaya J, Bossuyt X, Verschueren P, Westhovens R. The epidemiology of rheumatoid arthritis in Kinshasa, democratic republic of Congo - a population based study. Rheumatology (Oxford). 2012;51(9):1644-7.

3. Myllykangas-Luosujarvi $\mathrm{R}$, Aho $\mathrm{K}$, Kautiainen $\mathrm{H}$, Isomaki $\mathrm{H}$. Cardiovascular mortality in women with rheumatoid arthritis. J Rheumatol. 1995;22:1065-7.

4. Gabriel S, Crowson S, Kremers H, Doran M, Turesson C, O'Fallon W, et al. Survival in rheumatoid arthritis: a population-based analysis of trends over 40 years. Arthritis Rheum. 2003;48:54-8.

5. Solomon D, Karlson E, Rimm E, Cannuscio C, Mandl L, Manson J, et al. Cardiovascular morbidity and mortality in women diagnosed with rheumatoid arthritis. Circulation. 2003:107:1303-7.

6. Maradit-Kremers H, Nicola P, Crowson C, Ballman K, Gabriel S. Cardiovascular death in rheumatoid arthritis: a population-based study. Arthritis Rheum. 2005;52:722-32

7. Avina-Zubieta J, Choi H, Sadatsafavi M, Etminan M, Esdaile J, Lacaille D. Risk of cardiovascular mortality in patients with rheumatoid arthritis: a metaanalysis of observational studies. Arthritis Rheum. 2008;59:1690-7.

8. Van Halm V, Peters M, Voskuyl A, Boers M, Lems W, Visser M, et al. Rheumatoid arthritis versus diabetes as a risk factor for cardiovascular disease: a cross-sectional study, the care investigation. Ann Rheum Dis. 2009;68:1395-400.

9. Boyer J, Cantagrel A, Constantin A. Impact of traditional therapies and biologics on cardiovascular diseases in rheumatoid arthritis. Curr Vasc Pharmacol. 2008;6:218-27.

10. Gonzalez-Gay M, Gonzalez-Juanatey C, Ollier W. Endothelial dysfunction in rheumatoid arthritis: influence of HLA-DRB1 alleles. Autoimmun Rev. 2004:3:301-4

11. Pincus T, Brooks R, Callahan L. Prediction of long-term mortality in patients with rheumatoid arthritis according to simple questionnaire and joint count measures. Ann Intern Med. 1994;120:26-34.

12. Turesson C, McClelland R, Christianson T, Matteson E. Severe extra-articular disease manifestations are associated with an increased risk of first cardiovascular events in patients with rheumatoid arthritis. Ann Rheum Dis. 2007;66:70-5.

13. Mora S, Rifai N, Buring JE, Ridker PM. Comparison of LDL-c concentration by Friedewald calculation and direct measurement in relation to cardiovascular events in 27,331 women. Clin Chem. 2009;55(5):888-94. https://doi.org/10.13 73/clinchem.2008.117929.

14. Cohen E, Chapuis LN, Pasquet P, Gueye L, Boetsh G. L'image du corps chez les sénégalais, Application à l'étude de l'obésité, dans le contexte de transition épidémiologique. Anthropologie du vivant. 2010;12:52-7.

15. Marianne EG, Nomcampbell NS, Tazeen J, Tej K. Standards for the uniform reporting of hypertension in adult using population survey data : recommandations from the world hypertension league expert committee. J Clin Hypertens. 2014;16:773-81.

16. Krivitzky A. Les nouvelles recommendations ESC-EASD sur le diabète Guidelines on diabetes, prediabetes, and cardiovascular diseases : executive summary. La lettre du cardiologue. 2007:40:9-15.

17. Orth SR, Stockmann A, Conradt C, Ritz E, Ferro M, Kreusser W, et al. Smoking as a risk factor for end-stage renal failure in men with primary renal disease. Kidney Int. 2008;54:926-31.

18. Perneger TV, Whelton PK, Puddey IB, Klag MJ. Risk of end-stage renal disease associated with alcohol consumption. Am J Epidemiol. 1999; 150:1275-81.

19. Takeshi K, Laria P, Maufroy N, Detienne JP, Cuveillier D, Maureau I, et al. Hypertension artérielle et pression pulsée. Mt cardio. 2006;2(5):493-501.

20. Cook S, Ottom H, Lerch R, Luscher T, March F. Concepts et evidence de l'importance de la fréquence cardiaque de repos dans la prévention et la prise en charge des maladies cardiovasculaires. Cardiovasc Med. 2010;13:82-92.

21. Scott J, LeonardAK BE, PattySF RAG, Caroline RR, et al. Guide to the assessment of physical activity : clinical and reasearch application. Circulation. 2013:128:2259-79.

22. Chung CP, Oeser A, Solus JF, Avalos I, Gebretsadik T, Shintani A, et al. Prevalence of the metabolic syndrome is increased in rheumatoid arthritis and is associated with coronary atherosclerosis. Atherosclerosis. 2008;196(2): 756-63. https://doi.org/10.1016/j.atherosclerosis.2007.01.004.

23. Maradit-Kremers H, Nicola PJ, Crowson CS, Ballman KV, Gabriel SE. Cardiovascular death in rheumatoid arthritis: a population-based study. Arthritis Rheum. 2005;52:722-32.

24. Cohen S, Emery P. The American College of Rheumatology/European league against rheumatism, criteria for the classification of rheumatoid arthritis: a game changer. Ann Rheum Dis. 2010;69:1575-6.

25. Kassem E, Ghonimy R, Adel M, El-sharnoby G. Non traditional risk factors of carotide atherosclerosis in rheumatoid arthritis. Egypt Rheumatologist. 2011;33:113-9.

26. Gonzalez-Juanatey C, Llorca J, Testa A, Revuelta J, Garcia-Porrua C, GonzalezGay MA. Increased prevalence of severe subclinical atherosclerotic findings in long-term treated rheumatoid arthritis patients without clinically evident atherosclerotic disease. Medicine (Baltimore). 2003:82:407-13.

27. Carotti M, Salaffi F, Mangiagoti M, Cerioni A, Guiseppetti GM, Grassi W. Atherosclerosis in rheumatoid arthritis: the role of high-resolution B mode ultrasound in the measurement of the arterial intima-media thickness. Reumatismo. 2007:59(1):38-49.

28. Malemba JJ, Mbuyi-Muamba JM. Clinical and epidemiological features of rheumatic diseases in patients attending the university hospital in Kinshasa. Clin Rheumatol. 2008;27:47-54.

29. Malemba JJ, Mbuyi-Muamba JM, Mukaya J, Bossuyt X, Emmonds MP, Deiteren K, Westhovens R, Verschueren. The phenotype and genotype of rheumatoid arthritis in the Democratic Republic of Congo. Arthritis Res Ther. 2013;15(4):R89.

30. Felson DT. Epidemiology of the rheumatic diseases.In Arthritis and allied conditions: A textbook of rheumatology, 14th ed. Philadelphia: Lippincott Williams and Wilkins; 2001;2736p.

31. Roux H. Polyarthrite rhumatoïde en Afrique subsaharienne. Rév Rhum. 2002; 69:797-800

32. Mijiyawa M. Aspects sémiologiques et épidémiologiques des maladies rhumatismales en Afrique noire. Sem Hôpitaux Paris. 1995;71:912-23.

33. Nicaise-Roland P, Delaunay C, Meyer O, Labarre L. Les anticorps antipeptides cycliques citrullinés : intérêt dans la Polyarthrite Rhumatoïde. Immunoanalyse et Biologie Spécialisée. 2003;18:41-5.

34. Malemba JJ, Mbuyi-Muamba JM, Mukaya J, Bossuyt X, Verschueren P, Westhovens R. Treatment of rheumatoidarthritiswithmethotrexate in congolese patients. Clin Rheumatol. 2013;32(9):1323-7. 
35. Grover S, Sinha R, Singh U, Tewari S, Aggarwal A, Misra R. Subclinical atherosclerosis in rheumatoid arthritis in India. J Rheumatol. 2006;33:244-7.

36. Mahajan V, Handa R, Kumar U, Sharma S, Gulati G, Pandey RM, et al. Assessment of atherosclerosis by carotid intimomedial thickness in patients with rheumatoid arthritis. J Assoc Physicians India. 2008;56:587-90.

37. Mohan A, Sada S, Kumar BS, Sarma KV, Devi BV, Rao PV. Subclinical atherosclerosis in patient with rheumatoid arthritis by utilizing carotid intimamedia thickness as a surrogate marker. Indian J Med Res. 2014;140(3):379-86.

38. Philips J, Monique M, Scheen A. Modification en fonction de l'âge de la pression pulsée (PP), de la fréquence cardiaque (FC) et du double produit PP x FC évalués lors d'un test postural chez les patients avec un diabete de type 1. Diabete Metab. 2010;36:A51

39. Jonsson SW, Backman C, Johnson O, Karp K, Lundstrom E, Sundqvist KG, et al. Increased prevalence of atherosclerosis in patients with medium term rheumatoid arthritis. J Rheumatol. 2001:28:2597-602.

40. Alkaabi J, Ho M, Levison R, Pullar T, Belch J. Rheumatoid arthritis and macrovascular disease. Rheumatology. 2003;42:292-7.

41. Kumeda Y, Inaba M, Goto H, Nagata M, Henmi Y, Furumitsu Y, et al. Increased thickness of the arterial intima media detected by ultrasonography in patients with rheumatoid arthritis. Arthritis Rheum. 2002; 46:1489-97.

42. Park YB, Ahn CW, Choi HK, Lee SH, In BH, Lee HC, et al. Atherosclerosis in rheumatoid arthritis. Arthritis Rheum. 2002;46:1714-9.

43. Costanzo P, Perrone-Filardi P, Vassallo E, Paolitto S, Cesarano P, Brevetti G, et al. Does Carotid intima-media thickness regression predict reduction of cardiovascular events? A Meta-Analysis of randomized trials. J Am CollCardiol. 2010;56:2006-20.

44. Rossouw J, Prentice R, Manson J, Wu L, Barad D, Barnabei VM, et al. Postmenopausal hormone therapy and risk of cardiovascular disease by age and years since menopause. Jama. 2007;297:1465-77.

45. Dionicio A, Antonio E, Alberto G, Fernando G, Jorgeluis M, Griselda. Carotid atherosclerosis in patient with rhematoid arthritis and rheumatoid nodules. ReumatolClin. 2013:9(3):136-41.

46. Elshereef RR, Darwish A, Ali A, Abdel-kadar M, Hamdy L. Asymptomatic atherosclerosis in Egyptian rheumatoid arthritis patients and its relation to disease activity. Int J Rheumatol. 2015;2015:8. https://doi.org/10.1155/2015/381931.

47. Hannawi S, Haluska B, Marwick T, Thomas R. Atherosclerotic disease is increased in recent-onset rheumatoid arthritis: a critical role for inflammation. Arthritis Res Ther. 2007;9:R116.

48. Gonzalez-Gay MA, Gonzalez-Juanatey C, Vazquez-Rodriguez TR, MirandaFilloy JA, Llorca J. Insulin resistance in rheumatoid arthritis: the impact of the anti-TNF-atherapy. Ann N Y AcadSci. 2010;1193:153-9.

49. Vis M, Nurmohamed M, Wolbink G, Voskuyl A, de Koning M, van de Stadt R, et al. Short term effects of infliximab on the lipid profile in patients with rheumatoid arthritis. J Rheumatol. 2005;32:252-5.

50. Chung CP, Oeser A, Solus JF, Avalos I, Gebretsadik T, Shintani A, et al. Prevalence of the metabolic syndrome is increased in rheumatoid arthritis and is associated with coronary atherosclerosis. Atherosclerosis. 2008 Feb; 196(2):756-63. https://doi.org/10.1016/j.atherosclerosis.2007.01.004.

51. Prodromos I, Stylianos A, Dimitrios T. Metabolic syndrome in rheumatic diseases: epidemiology, pathophysiology, and clinical implications. Arthritis Res Ther. 2008;10:207-16.

\section{Publisher's Note}

Springer Nature remains neutral with regard to jurisdictional claims in published maps and institutional affiliations.

Ready to submit your research? Choose BMC and benefit from:
- fast, convenient online submission
- thorough peer review by experienced researchers in your field
- rapid publication on acceptance
- support for research data, including large and complex data types
- gold Open Access which fosters wider collaboration and increased citations
- maximum visibility for your research: over 100M website views per year
At BMC, research is always in progress.
Learn more biomedcentral.com/submissions

